\title{
Motstridende mål i kroppsøving i Norge - en analyse av læreplanene i faget i perioden 2006 til 2015
}

\author{
Idar Lyngstad $\star$ \\ Nord universitet
}

\section{Sammendrag}

Siden 2006 har læreplanens formål og kompetansemål i kroppsøving i norsk skole blitt endret i 2012 og 2015. I denne artikkelen er det foretatt en analyse av endringer i formål og kompetansemål i læreplanene i kroppsøving i perioden fra og med 2006 til 2015. Grunnlaget for analysen er hentet fra teori om kroppsøvingsfagets mål og begrunnelse av Peter J. Arnold (1988) og Claes Annerstedt (2001). Analysen viser at målformuleringene i læreplanene har blitt utviklet i et spenningsfelt mellom et ferdighets- og prestasjonsfokus, som definerer måloppnåelse hos eleven etter forhåndsdefinerte fysisk-motoriske kriterier og rene idrettslige prestasjoner på den ene siden, og på den andre siden mål om individuell ferdighetslæring som definerer måloppnåelse etter øvings- og treningsprinsipper som er relevante for å oppnå kroppslig utvikling og helse ut ifra elevens læreforutsetninger, som er ulike. Kunnskapsdepartementet forsøker å ivareta to ulike forståelser om mål i kroppsøving som det er krevende å forene $\mathrm{i}$ et helhetlig fagsyn i læreplanen. Læreplaner i framtiden vil trolig også utvikles i et spenningsfelt mellom disse ulike forståelsene av formål og kompetanser i faget, men det er usikkert hvor fruktbart dette vil være.

Nøkkelord: Kroppsøving; kompetanse; nasjonale prøver; svømming; lareplananalyse

\section{Abstract \\ Contradictory aims in PE in Norway - An analysis of the national curriculum in PE from 2006 to 2015}

Since 2006, aims in the National Curriculum for physical education (PE) have been revised in 2012 and 2015. In this study, the revisions in the period from 2006 to 2016 are analyzed in the light of perspectives on aims in PE by Peter J. Arnold (1988) og Claes Annerstedt (2001). The curriculum has been revised in an area of tension between performance aims, which are defined from external standards, and individual development aims, which are defined from internal standards and on the basis of training principles, which are used to attain individual improvement and health. The analysis shows that the curriculum allowed for more individual and differentiated aims in 2012, compared with the curriculum in 2006. Through revisions in 2012 and 2015, the ministry signals that internal standards and individual and differentiated aims are important in PE, but at the same

^Korrespondanse: Idar Lyngstad, epost: idar.k.lyngstad@nord.no

(C) 2019 I. Lyngstad.This is an Open Access article distributed under the terms of the Creative Commons Attribution 4.0 International License (https://creativecommons.org/licenses/by-nc/4.0/), allowing third parties to copy and redistribute the material in any medium or format and to remix, transform, and build upon the material for any purpose, even commercially, provided the original work is properly cited and states its license. 
time performance aims, which are defined from external standards, are also relevant. The ministry tries to ensure two perspectives on aims that are difficult to unite in an overall view on PE. The national curriculum for PE will probably evolve in an area of tension between the two aims perspectives also in the future, but it is unclear how fruitful it will be.

Keywords: Physical education; competence; national test; swimming; curriculum analysis

Received: April, 2018; Accepted: May, 2019: Published: November, 2019

\section{Innledning}

Siden Kunnskapsløftet trådte i kraft i Norge i 2006 har mål i læreplanen i kroppsøving blitt endret både i 2012 og 2015. Formål og kompetansemål i læreplanen fra 2006 ble endret i 2012 (Utdanningsdirektoratet, 2012) etter at denne læreplanen skapte usikkerhet omkring kompetansemål og fagets vurderingsordning hos både lærere og elever (Vinje, 2016). I 2015 ble læreplanen endret ved at kompetansemål i tilknytning til svømmeopplæringen på årstrinnene 1-4, 5-7 og 8-10 ble omformulert eller erstattet med nye målformuleringer (Utdanningsdirektoratet, 2015).

Historisk går det en sentral linje fra tidligere læreplaner i kroppsøving, der faget før 2006 ble satt i tilknytning til elevens allmenne kunnskapsutvikling, selvforståelse og identitetsvekst, og til gjeldende læreplan, som vektlegger ferdigheter og kunnskap ut i fra egne forutsetninger, bevegelsesglede og innsats $i$ forbindelse med bevegelsesaktivitet (Ommundsen, 2016). Kompetansemålene i læreplanen i kroppsøving i 2006 la imidlertid opp til at elevene skulle oppfylle mål som var definert etter standarder fra ulike idrettslige praksiser i større grad enn før (Arnesen, Nilsen \& Leirhaug, 2013). Dette skapte et brudd med tidligere læreplaner. Jevnlige oppslag i media i årene etter 2006 opplyste at elever opplevde et press $\mathrm{i}$ forbindelse med testing og prestasjonsforventninger i undervisningen, og at lærere var mest opptatt av aktiviteter som kunne observeres og måles for å kunne dokumentere elevers ferdigheter og prestasjonsnivå og sette rettferdige karakterer (Se for eksempel artikkel i Aftenposten, 23. 11, 2010, hvor kunnskapsminister Halvorsen lover full gjennomgang av kroppsøving). Læreplanen så samtidig bort fra elevens innsats i timene, som også hadde vært sentralt i faget tidligere, og som eleven kunne bli vurdert etter. Når læreren kom til karaktersetting, skulle ikke eleven vurderes på grunnlag av innsats i timene (Vinje \& Brattenborg, 2016). Reaksjonene fra både elever og lærere i kroppsøving påvirket utdanningsmyndighetene til å revidere læreplanen i kroppsøving i 2012 (Arnesen et al., 2013).

I foreliggende studie analyseres endringer i formål og kompetansemål i læreplanen i perioden fra og med 2006 og til 2015 med utgangspunkt i teori om mål og begrunnelse for faget kroppsøving av Peter J. Arnold (1988) og Claes Annerstedt (2001). Arnolds og Annerstedts begreper og teori har blitt anvendt i flere analyser av mål i kroppsøving, blant andre av Ommundsen (2016) og Lyngstad (2013), og gir et konstruktivt grunnlag for en analyse av formål og kompetansemål i læreplanen. 


\section{Lyngstad}

I foreliggende analyse belyses et spenningsfelt i denne læreplanutviklingen, mellom et ferdighets- og prestasjonsfokus som legger til rette for undervisningspraksis der måloppnåelse hos eleven vurderes etter ytre, idrettslige standarder, og et individuelt utviklingsfokus som definerer måloppnåelse ut i fra et annet syn på kompetanse i kroppsøving. Mens et ferdighets- og prestasjonsfokus defineres etter kriterier for fysisk-motoriske og idrettslige ferdigheter som er satt opp på forhånd, defineres et indviduelt utviklingsfokus ut i fra øvings- og treningsprinsipper som er relevante for å oppnå kroppslig utvikling og helse hos den enkelte elev ut i fra forutsetninger, som er ulike.

Samtidig vil jeg drøfte typen kompetansemål som er brukt i forbindelse med endring av ett kompetansemål i læreplanen i kroppsøving i 2015, nærmere bestemt et kompetansemål om svømmedyktighet og livbergingsferdighet etter 4. årstrinn. Dette kompetansemålet står i kontrast til andre kompetansemål i læreplanen fra 2012 fordi det beskriver en helt presis atferd hos eleven. Selv om dette målet er det eneste som beskriver elevens kompetanse så konkret i læreplanen i 2015, vil en drøfting av dette kompetansemålet ta opp en viktig måldebatt i kroppsøving. Kompetansemålet om svømmedyktighet og livbergingsferdighet illustrerer et ferdighets- og prestasjonsfokus på en tydelig måte, $\mathrm{i}$ kontrast til mål som har individuelt utviklingsfokus. Samtidig vil jeg problematisere innføringen av nasjonale prøver i forbindelse med kompetansemålet om svømmedyktighet og livbergingsferdighet (fra og med skoleåret 2016-2017), og innlemme en kommentar til den siste tids læreplanutvikling i faget i form av kjerneelementer som er vedtatt i den såkalte «Fagfornyelsen» (Utdanningsdirektoratet, 2018).

I analysen blir det delvis også referert til andre læreplananalyser, blant andre av Ommundsen (2016), Vinje (2016) og Säfvenbom (2010). Samtidig bør nevnes at flere forskere her til lands har bidratt til å opplyse og drøfte mål i læreplanen, for eksempel Zoglowek (2006), Dowling (2010), Standal (2015), Engebretsen (2016), Esser-Noetlichs, (2016), Kvikstad \& Sandell (2016), og Møller (2016), men disse blir ikke trukket inn i foreliggende analyse.

Det hører med å opplyse at jeg har vært involvert i læreplanarbeid i Utdanningsdirektoratet i forbindelse med revideringen av læreplanen i 2012 og i arbeidet med planen i «Fagfornyelsen». I 2012 var jeg leder for Utdanningsdirektoratets læreplangruppe, og i 2018 medlem i læreplangruppen. Disse engasjementene har gitt meg godt innblikk i læreplanutviklingen i perioden fra 2006 til 2015, og jeg har hatt anledning til å delta i relativt mange diskusjoner om mål i kroppsøving på bakgrunn av disse engasjementene, både innenfor og utenfor Utdanningsdirektoratets vegger. Under arbeidet med revidering av kompetansemål i svømmeopplæringen i 2015 hadde jeg ingen rolle og var kun observatør fra utsiden.

\section{Analysegrunnlag}

Her vil jeg gjøre kort rede for Arnolds og Annerstedts begreper og teori. Deres teorier har mange likhetstrekk og har i stor grad til felles at de beskriver at allsidig 
kroppslig læring og praktisk kunnskap er kjernen i kroppsøvingsfaget og at det er tre sentrale læringsdimensjoner i tilknytning til den sentrale praktiske kunnskapen i faget. Disse dimensjonene er læring $i$ bevegelse, læring om bevegelse og læring gjennom bevegelse. Med læring $i$ bevegelse menes læring $i$ et bredt spekter av aktiviteter som normalt finnes i bevegelseskulturer som omgir elevene (Arnold, 1988). Arnold mener at kroppsøving i skolen primært bør handle om å øve på varierte aktiviteter og lære fysiske ferdigheter som finnes i bevegelseskulturer som kan være forskjellige i lokalmiljøer. Læring om bevegelse refererer til teoretisk og faktisk kunnskap som er viktig i forbindelse med, eller som grunnlag for, utøvelse av bevegelsesaktivitet. Denne dimensjonen omfatter informasjon en kan innhente om ulike aktivitetsformer, informasjon som hjelper til å plassere aktiviteter i en sammenheng og giøre dem forståelige. Denne dimensjonen inneholder for eksempel å lære hva en idrettsaktivitet går ut på, og hvordan regler gjør en idrett morsom, spennende og utfordrende (Annerstedt, 2001). Læring gjennom bevegelse omhandler instrumentell bruk av kroppen (Arnold, 1988), der for eksempel andre mål enn kroppsøvingsmål kan nås, eller at ønskelige sideeffekter kan oppnås, for eksempel helseeffekter og fritidsvaner (Annerstedt, 2001). Denne dimensjonen beskriver altså først og fremst hvordan bevegelse anvendes for å nå andre mål enn de rent bevegelsesmessige og praktiske.

Arnold (1988) mener at i- og om-dimensjonene beskriver hva som er bevegelsens selvstendige verdi, eller egenverdi, mens giennom-dimensjonen viser hva som er bevegelsesaktiviteters nytteverdier. Både egenverdien og nytteverdier ved bevegelse legitimerer kroppsøving i skolen, hevder Arnold, men presiserer at i- og om-dimensjonene er det viktigste grunnlaget for fagets plass i utdanningssystemet. Nytteverdier ved bevegelse kan aldri alene legitimere faget i skolen, mener han.

Annerstedt (2001) er på linje med Arnolds teori når det gjelder i- og omdimensjonenes primat. Annerstedt utdyper samtidig at bevegelse som fenomen representerer verdier som er fundamentale for menneskers eksistens og selvutvikling. Mennesket har evne til å reflektere over egen bevegelse og til å forstå seg selv og omverden i tilknytning til bevegelsesaktivitet. Viktig informasion om en selv i bevegelse innhentes blant annet gjennom den kinestetiske sans. Den kinestetiske sans er viktig for et hvert menneske, ettersom det er en kilde til informasjon om en selv når en beveger seg, som bare er tilgjengelig mens en er i bevegelse. Det er det samme som å si at en elev kan kjenne og erfare en bevegelse, men ikke fullt og helt før eleven giør selve bevegelsen. Her kan kroppsøvingsfaget bidra til å utvikle viktig praktisk kunnskap hos eleven, mener Annerstedt. I tillegg hører det også med å utvikle en evne til å se bevegelsesaktivitet i en utvidet og kritisk sammenheng $\mathrm{i}$ samfunnet, eksempelvis se alternative bevegelsesformer i samfunnet og å forholde seg kritisk til bevegelseskulturer en blir stilt overfor. Dette er også en del av Annerstedts teorisyn.

Hva så med læreplanene fra 2006, 2012 og 2015 i lys av Arnold og Annerstedts begreper og teori? Disse læreplanene blir belyst og drøftet videre i neste avsnitt. 


\section{Lyngstad}

\section{Læreplanene i kroppsøving fra 2006, 2012 og 2015}

Læreplanen i kroppsøving i 2006 (Utdanningsdirektoratet, 2006) tonet ned tidligere mål som ble satt i tilknytning til elevens allmenne kunnskapsutvikling, selvforståelse og identitetsvekst, som nevnt tidligere (Ommundsen, 2016). Kunnskap som var relevant for å oppnå kroppslig utvikling og helse hos den enkelte elev ble mindre vektlagt (Arnesen et al., 2013). Læreplanen 2006 la vekt på at eleven skulle tilegne seg fysisk-motoriske ferdigheter og bestemte kunnskaper, og kompetansemålene i planen la til rette for ferdighetsmål i konkrete attferdstermer i lokale læreplaner i større grad enn før (Arnesen et al., 2013). Kompetansemål som vektla læring av fysisk-motoriske ferdigheter og tilegnelse av bestemt kunnskap omhandlet for eksempel at eleven skulle utvikle ferdigheter i utvalgte idretter, så videreutvikle disse ferdighetene, for så til slutt å mestre en aktivitet/idrett (ved slutten av videregående opplæring). Innenfor hovedområdet «Idrett og dans» i videregående opplæring het det for eksempel at eleven skulle utvikle ferdigheter $\mathrm{i}$ individuelle idretter og lagidretter på videregående trinn 1, videreutvikle ferdigheter i individuelle idretter og lagidretter på trinn 2 og til slutt mestre en individuell idrett og en lagidrett på trinn 3 (Utdanningsdirektoratet, 2006, mine kursiver). Disse kompetansemålene la opp til ferdighetslæring som tok sikte på å mestre en individuell idrett og en lagidrett i trinn 3 på basis av lokalt fastsatte kriterier for hva å mestre tilsier.

Mestring kunne i forbindelse med disse kompetansemålene bli målt og vurdert ved fysisk-motoriske og idrettslige tester, blant annet i løpstester, der tilbakelagt distanse over en viss tid ble målt, eller i teknikkøvelser i idretter (Vinje, 2016). Måloppnåelse - og dermed mestring, samt en god tallkarakter - ble vurdert etter kriterier fastsatt på forhånd om for eksempel løpsutholdenhet etter tidtabeller eller utførelse av teknikk eller taktiske strategier $\mathrm{i}$ henhold til normerte beskrivelser i idretter (Arnesen et al., 2013).

Selv om det er grunn til å hevde at læreplanen i 2012 følger i flere spor fra den forrige læreplanen, og på mange måter er nokså lik denne planen (for eksempel er oppdelingen i hovedområder nesten den samme som i tidligere læreplan), er det foretatt endringer i fagets formål og kompetansemål som gjør at den samtidig er ulik læreplanen fra 2006. Læreplanen 2012 står i relativt stor kontrast til læreplanen 2006 når det gjelder syn på mål, og den preges mer enn den tidligere planen av et syn på mennesket som kroppslig subjekt, selvrefleksjon og identitetsdanning i forbindelse med bevegelsesaktivitet. I fagets formål heter det at opplæringen skal medvirke til at eleven utvikler allsidige fysiske ferdigheter og opplever glede, inspirasion og selvforståelse ved å være i kroppslig bevegelse, i friluftslivsaktiviteter og i felles aktivitet sammen med andre. Bevegelseskultur i form av leik, idrett, dans og friluftsliv er en del av den felles dannelsen og byggingen av identitet i samfunnet, og kroppsøvingsfaget er viktig for barn og unge for å ta del i bevegelseskulturen i samfunnet (Utdanningsdirektoratet, 2012, utdrag fra avsnittet «Føremål» i læreplanen i kroppsøving). Det er videre tatt inn i læreplanen at eleven skal se idrett og fysisk aktivitet i en utvidet og kritisk 
sammenheng i samfunnet og forholde seg kritisk til den bevegelseskultur han eller hun blir stilt overfor, ved for eksempel å forklare på hvilken måte ulike kroppsidealer og bevegelseskulturer kan påvirke trening, livsstil og helse. (Utdanningsdirektoratet, 2012, kompetansemål etter 10. årstrinn i læreplanen).

Kompetansemålene i læreplanen er med andre ord kontrastfull til læreplanen 2006 i synet på kroppslig laring. Kroppslig læring og bevegelseskompetanse, her uttrykt i vid forstand, ikke bare i form av tradisjonelle idrettsaktiviteter, tilsier at kroppsøvingsfaget er en arena for helhetlig menneskelig utvikling mer enn bare i et fysisk-motorisk og idrettslig prestasjonsperspektiv, som læreplanen fra 2006 ble kritisert for å fokusere for mye på. Samtidig uttrykker læreplanen fra 2012 at kroppsøving skal gi eleven samfunnsrelevant erfaringsgrunnlag og handlingskompetanse til å kunne delta i allmenn lek-, spill- og idrettskultur. God motorisk kompetanse representerer kroppslig kapital som eleven kan bruke i fritidsaktivitet i sin oppvekst (Ommundsen, 2016). Denne kompetansen skaper ikke bare grobunn for deltagelse og mestring, men også for kunne reflektere kritisk over ulike forhold omkring organisert idrett så vel som den allmenne leke-, spill- og idrettskulturen eleven er del av, eller som eksisterer i elevens lokalmiljø, noe Annerstedt (2001) påpeker som viktig kompetanse i kroppsøving.

\section{Læreplanen fra 2012 legger vekt på innsats}

En viktig endring i læreplanen i 2012 er i tillegg at den legger vekt på elevens innsats i timene, spesielt sett opp i mot to sentrale mål i faget, en livslang bevegelsesglede og en fysisk aktiv livsstil. Dette betyr at det er et viktig faglig mål å kunne trene for å forbedre ferdigheter og oppnå fysisk form, det vil si praktisk anvende kunnskap om trening med sikte på egen utvikling. Eleven som viser praktisk kunnskap (Annerstedt, 2001) med tanke på forbedring og egen utvikling, og som arbeider målrettet og ikke gir opp, skjønner således et viktig faglig poeng i kroppsøving og sørger for måloppnåelse på et sentralt område i faget.

I tillegg bygger kompetansemålene i læreplanen fra 2012 i større grad enn den forrige planen på prinsippet om at det ikke er rimelig å forvente at alle elever oppnår like høy grad av måloppnåelse når det gjelder absolutte praktiske kunnskaps- og ferdighetsmål på grunn av ulike forutsetninger for kroppslig bevegelse og idrettslig prestasjonsevne. Da det ble innført kompetansemål om at eleven skal kunne trene med sikte på å forbedre fysisk-motoriske ferdigheter i ulike aktivitetsformer, eller planlegge og gjennomføre trening med tanke på egen kroppslige utvikling og helse (kompetansemål i hovedområdene «Idrettsaktivitet», årstrinn 8-10 og "Trening og helse», årstrinn 8-10), ble det tatt hensyn til elevenes ulike læreforutsetninger. Altså ble ikke kompetansemål som la grunnlag for undervisningspraksis med sikte på at elevene skulle oppnå like fysisk-motoriske og idrettslige ferdigheter vektlagt i like stor grad i læreplanen i 2012 som i planen i 2006.

Derimot fikk et individuelt utviklingsfokus større plass. Et individuelt utviklingsfokus i læreplanen omhandler først og fremst mål om å praktisere prinsipper for 


\section{Lyngstad}

trening og gjennomføre opplegg for å oppnå relevante, individuelle mål om kroppslig utvikling og helse, som er nevnt tidligere, noe som alle elever uansett forutsetninger kan få til. Dette fremmer igjen den viktige betydningen av innsats, fysisk aktivisering og varige aktivitetsvaner ut i fra egne forutsetninger, samt selvledelse under trening (Säfvenbom, 2010). Dette føyer seg også inn i teori om kroppsøving som omhandler at bevegelsesaktivitet og kroppslig læring fremmer positiv selvforståelse, personlighetsutvikling og identitetsfølelse. Bevegelseskompetanse vil kunne bidra til at barn og unge får kraft til å ta hånd om eget liv og til å se seg selv som kompetente i eget liv (Annerstedt, 2001).

Samtidig ble det innført andre kompetansemål som passet inn i dette perspektivet. Det heter blant annet i læreplanen at faget skal få elevene bevisste på psykiske, fysiske, og sosiale faktorer som kan påvirke motivasjonen og lysten til å trene dette er hentet fra kompetansemål om at eleven skal giøre rede for faktorer som påvirker motivasjonen til aktivitet og trening etter trinn 1 i videregående opplæring, hovedområdet «Trening og livsstil». Det heter også at faget skal fremme kritiske holdninger til kroppsidealer og bevegelseskulturer i samfunnet som kan påvirke elevenes kroppslige selvbilde og treningsinnsats, ofte på en uheldig måte (kompetansemål om at eleven skal kunne forklare hvordan ulike kroppsideal og ulike bevegelseskultur påvirker trening, ernæring, livsstil og helse etter 10. årstrinn, hovedområdet «Trening og livsstil»). Faget skal også gi elevene en større frihet til å prøve ut seg selv i forhold til et mangfold av bevegelsesidealer som preger det moderne samfunn, og som spesielt eksisterer i barn og unges egen kultur (Det er et kompetansemål om at eleven skal kunne trene på og bruke ulike ferdigheter i utvalgte lagidretter, individuelle idretter og alternative bevegelsesaktiviteter etter årstrinn 10).

\section{Endringer i kompetansemål fra 2015}

I 2015 ble det endret kompetansemål i tilknytning til svømmeundervisningen på årstrinnene 1-4, 5-7 og 8-10 i læreplanen, og et endret kompetansemål etter 4 . årstrinn gjør det tydelig hva som forventes av eleven når det gjelder å bli svømmedyktig. Dette kompetansemålet står i kontrast til kompetansemålene som preger læreplanen fra 2012 ved at det skiller seg ut som type kompetansemål. Uansett hvilke læreforutsetninger eleven har, gjelder samme - og absolutte - ferdighetskrav for å oppnå kompetansemålet. Ingen av de andre kompetansemålene i lærerplanen er så konkret i beskrivelsen av atferd som dette målet i svømming etter 4 . årstrinn, heller ikke de andre kompetansemålene som ble endret i tilknytning til svømmeopplæringen på årstrinnene 5-7 og 8-10. Dette kompetansemålet vil jeg nå se nærmere på. I læreplanen fra 2015 på trinn 1-4 om svømmedyktighet og livbergingsferdighet heter det at eleven skal kunne falle ut i vann, bruke svømmeteknikker over relativt lang distanse, dykke, holde seg flytende i vannet og ta seg opp av vannet, etter eksakte og klare krav. Helt presist er kompetansemålet formulert slik: «Eleven skal kunne falle ut i på dypt vann, svømme 100 meter på magen, dykke ned og hente en gjenstand med hendene, stoppe og hvile i 3 minutter (i mens flyte på magen, 
orientere seg, rulle over, flyte på rygg), så svømme 100 meter på rygg og ta seg opp på land» (Utdanningsdirektoratet, 2015, s. 6.).

Samtidig ble det innført nasjonale prøver i svømme- og livbergingsferdighet i forbindelse med det endrede kompetansemålet i svømmeopplæringen etter 4. årstrinn (Utdanningsdirektoratet, 2016). Kunnskapsdepartementet la til grunn for denne bestemmelsen at det var bekymringsfullt at om lag 50 prosent av tiåringene i skolen ikke innfridde krav i svømming om å være trygg i vann og svømmedyktig (opplyst i samme pressemelding), og ville derfor ha nasjonale prøver som skulle kartlegge i hvilken grad elevene var svømmedyktige og hadde livbergingsferdighet etter fjerde skoleår fra og med skoleåret 2017-2018.

Nærmere drøfting av kompetansemålet om svømme- og livbergingsferdighet etter 4 . årstrinn samt nasjonal prøve

På den ene siden er det grunn til å gi tilslutning til Kunnskapsdepartementets ambisjon om å styrke svømmeopplæringen i skolen og forplikte skolene til å øke kvalitet og omfang på svømmeundervisningen, slik at elevene tilegner seg svømme- og livbergingskompetanse. Det kan dessuten være faglig relevant å operasjonalisere svømmedyktighet og lage en beskrivelse som gjelder for alle lærere og skoler i form av et kompetansemål i læreplanen. På den andre siden er det (minst) en potensiell uheldig virkning av endringen av kompetansemålet i svømming på årstrinn 1-4. En konsekvens kan nemlig være at mål om individuell utvikling ut ifra forutsetninger og bevegelsesglede, som tidligere er blitt belyst som viktig i faget, skyves til siden i svømmeundervisningen for de yngste elevene. Den pedagogiske praksisen lærerne utformer kan stå i fare for å være i strid med viktige deler av formålet i kroppsøving, at undervisningen skal medvirke til at alle elever opplever bevegelsesglede, inspirasjon og styrket selvforståelse ved kroppslig bevegelse og læring, uavhengig av forutsetninger og læreevne. Det vil trolig være en del elever som vil ha problemer med å bestå den nasjonale prøven, ettersom svømme- og livbergingskravet må kunne sies å være krevende for en tiåring. De vil imidlertid måtte strebe mot å oppfylle kompetansemålet. Mye tid må trolig brukes i kroppsøvingsundervisningen for at alle elevene skal oppnå svømmedyktigheten etter denne atferdsspesifikasjonen fra Kunnskapsdepartementet, og det er spesiell grunn til bekymring for elevene som vil ha vansker eller ikke har læremessige forutsetninger til å oppfylle kravene til svømmedyktighet.

I 2012 ble læreplanen i kroppsøving nettopp endret, som nevnt, fordi læreplanen fra 2006 skapte et ferdighets- og prestasjonsfokus i undervisningen som var uheldig. I tidligere studier, både nasjonalt og internasjonalt, er det funnet at noen elever synes at kroppsøving er et krevende og problematisk fag, at kroppsøvingstimer preges av negative læringserfaringer, og at det er vanskelig å få positive opplevelser i kroppsøvingstimene (Cardinal, Yan, \& Cardinal, 2013; Enright \& O'Sullivan, 2010; Fisette, 2011; Lyngstad, Hagen, \& Aune, 2016; Säfvenbom, Haugen, \& Bulie, 2015; Tischler \& McCaughtry, 2011; van Seelen, 2012). I forskningslitteraturen er det derfor blitt 


\section{Lyngstad}

drøftet at det er gunstig å ha mål i kroppsøvingsundervisningen som tar hensyn til elevens forutsetninger og læreevner i faget på alle opplæringstrinn, og som omhandler å praktisere prinsipper for trening og øve for å oppnå relevante, individuelle mål om kroppslig utvikling, bevegelsesglede- og helse. Ikke minst er slike kompetansemål ansett som viktig for å ivareta bevegelsesglede og en aktivitetslyst som vedvarer (Fisette, 2011; Lyngstad et al., 2016; van Selen, 2012).

I forbindelse med kompetansemålet om svømmedyktighet er det samtidig spesiell grunn til å problematisere nasjonale prøver i svømme- og livbergingsferdighet. Nasjonale prøver er nyttige for skoleeier og departement fordi en får en kartlegging som har verdi for dem (for å få oversikt over andelen av elevene som er svømmedyktige), og det kan være at svømmelærere mener at nasjonale prøver har positiv verdi i det pedagogiske opplegget i svømming. Men for elevene er det fare for at nasjonale prøver drukner svømmegleden, eller at det glipper andre viktige ting som er forbundet med svømming. Det er for eksempel en spesiell perseptuell og kinestetisk erfaring i seg selv å lære seg å svømme. Denne erfaringen er en viktig type læringserfaring i faget kroppsøving, i det den referer til viktig form for kroppslig læring i barneårene (Annerstedt, 2011; Arnold, 1998). Mange elever lærer å svømme i skolen. Det er en spesiell kinestetisk følelse å kjenne at en flyter i vannet i bassenget, svømmer framover, og faktisk behersker vannet, sammenlignet med situasjonen tidligere der flyt og framdrift i vannet var fraværende. Denne svømmeerfaringen er en umiddelbar kroppslig erfaring, som oppstår i det øyeblikket der svømmebevegelsen i vannet lykkes og flyt og framdrift oppnås. På samme tid oppleves gjerne begeistring og bevegelsesglede (Lyngstad, 2014). I Arnolds og Annerstedts syn på læring i kroppsøving vektlegges nettopp en slik erfaring, og mange andre lignende læringserfaringer. De er viktige for en ung elevs faglige utvikling i kroppsøving, selv om elevens ferdighet $-\mathrm{i}$ dette tilfelle svømmeferdigheten på årstrinn 1-4-ikke strekker til å svømme mer enn 50 meter i løpet av skoleårene 1-4.

Det er grunn til å bemerke at dette paradoksalt vil gi vurderingen «ikke bestått» på den nasjonale svømme- og livbergingsprøven, ettersom eleven må svømme minst 100 meter på magen og 100 meter på rygg som del av svømme- og livbergingsprøven. Den umiddelbare og viktige erfaringen å lære seg å svømme står altså i fare for å komme i skyggen av kravene som stilles i den nasjonale prøven i svømmeundervisningen.

Den subjektive erfaringen av å lære seg å svømme, og opplevelsen, som altså er noe annet enn de faktiske svømme- og livbergingsferdigheter, er vanskelig å knytte til det rent atferdsmessige, samt vanskelig å vurdere. På den annen side er erfaringen, opplevelsen og læringen viktig, om enn på en annen måte enn svømme- og livbergingsferdigheten som oppfyller definisjonen av svømmedyktighet i kompetansemålet i læreplanen. Og kanskje er denne læringserfaringen like relevant som karakteren «bestått» på en svømme- og livbergingstest, nettopp i lys av kroppsøvingsfagets formål, som vektlegger allsidig bevegelseslæring, bevegelsesglede og inspirasjon til å være fysisk aktiv hos de unge elevene? 


\section{Motstridende signaler om målfokus}

En konsekvens av at læreplanen inneholder ulike typer kompetansemål, er at departementet gir motstridende signaler om målfokus i læreplanen. Selv om kompetansemålet om svømmedyktighet kun gjelder for årstrinn 1-4, og er det eneste i sitt slag i gjeldende læreplan, gir departementet signaler som strekker seg ut over dette kompetansemålet og dette opplæringstrinnet. Kan det skje at et ferdighets- og prestasjonsfokus brer om seg i faget igjen, slik det gjorde etter at læreplanen i 2006 trådte i kraft, og på hvilken måte vil eventuelle nye læreplanendringer etter 2015 bidra til en slik utbredelse? Hva skjer ved neste korsvei, når læreplanen gjennomgås og vurderes i forbindelse med gjennomgangen av alle fag i skolen i Fagfornyelsen? Hvilke typer kompetansemål kommer i neste læreplan i kroppsøving? Kunnskapsdepartementet ga signal i 2015 om at ferdighetsmål etter ytre standardiserte (prestasjons)beskrivelser for hva måloppnåelse tilsier er relevante i lokale læreplaner og at måloppnåelse i kroppsøving også gjelder etter ferdighetskriterier som er absolutte - og like - for alle (jamfør typen kompetansemål som målet om svømmedyktighet og livbergingsferdighet representerer). Samtidig skal det foregå individuell ferdighetslæring ut i fra elevenes forutsetninger, som kan være ulike, ettersom dette signalet ble gitt på en tydelig måte gjennom kompetansemål i læreplanen fra 2012.

Her ønsker jeg å kommentere at som del av «Fagfornyelsen» er det beskrevet tre kjerneelementer i kroppsøving (Utdanningsdirektoratet, 2018). Disse er «bevegelse og kroppslig læring», «deltakelse og samspill i bevegelsesaktiviteter» og «Uteaktiviteter og naturferdsel». I utdypingen av disse kjerneelementene bruker Utdanningsdirektoratet formuleringer som viderefører sentrale mål og begrunnelser for faget fra tidligere læreplaner. Bevegelse beskrives som grunnleggende hos mennesket og basis for å fremme god helse. Å delta, skape og uttrykke seg i bevegelse, utforske egne muligheter og forbedre egne ferdigheter har egenverdi. Kjerneelementene viderefører synet på mennesket som kroppslig subjekt, selvrefleksjon og identitetsdanning i forbindelse med bevegelsesaktivitet. Samtidig understreker Utdanningsdirektoratet at kroppsøving skal gi elevene utfordringer og oppgaver i et læringsfelleskap der det er ulikhet og mangfold i elevgruppen. I mange bevegelsesaktiviteter og i naturferdsel framheves at deltakelse, medvirkning og samarbeid er nødvendig for å fremme læring for seg selv og andre, og kroppsøvingsfaget skal gi variert anledning til å praktisere og reflektere over samspill, medvirkning og likeverd.

\section{Konklusjon}

I videre læreplanutvikling vil det trolig bli diskusjoner om et ferdighets- og prestasjonsfokus i læreplanen opp i mot et syn som vektlegger kunnskap om øvings- og treningsprinsipper som er relevante for å oppnå kroppslig utvikling hos den enkelte ut i fra elevens egne forutsetninger. Nye læreplaner vil i framtiden også utvikles i et spenningsfelt mellom et ferdighets- og prestasjonsfokus på den ene siden, der standarder fra idrettslige praksiser utenfor kroppsøving gjerne blir brukt som vurderingskriterier 


\section{Lyngstad}

for alle elevene, og indre regulerte mål om kroppslig utvikling på den andre siden, der det ligger til grunn et annet syn på kompetanse. Det er imidlertid usikkert hvor fruktbart dette vil være. Kjernelementene i kroppsøving i «Fagfornyelsen» legger grunnlag for kompetansemål i læreplanen som legger vekt på indre regulerte mål om kroppslig læring, og ikke mål som skaper et ferdighets- og prestasjonsfokus, men det vil samtidig være merkelig hvis kompetansemålet om svømmedyktighet og livbergingsferdighet fjernes etter bare kort virketid.

Gjennom endringer i læreplanen i perioden 2006 til 2015 gir Kunnskapsdepartementet signaler om at det vil ivareta de to ulike forståelsene om mål i læreplanen, som det er krevende å forene i et helhetlig fagsyn. Det gjenstår å se hvilken innvirkning det endrede kompetansemålet i svømming i 2015 får, både kortsiktig og langsiktig (for eksempel hvorvidt det videreføres i ny læreplan), samt hvilken effekt tilhørende nasjonal prøve får. Men det vil ikke overraske dersom det kommer negative reaksjoner fra lærere, elever og foresatte, på samme måte som det kom reaksjoner fra lærere og elever etter at læreplanen i 2006 trådte i kraft, samt at eventuelle nye forsøk på å vektlegge et ferdighets- og prestasjonsfokus i framtidige læreplaner også vil skape reaksjoner.

\section{Forfatteromtale}

Idar Lyngstad er førsteamanuensis ved Nord universitet, fakultet for lærerutdanning og kunst- og kulturfag. Han har doktorgrad i pedagogikk fra NTNU og har publisert forskningsartikler innenfor kroppsøving. Han ledet Utdanningsdirektoratets arbeidsgruppe i kroppsøving $\mathrm{i}$ forbindelse med revisjon av læreplan i 2012 og var leder for en nasjonal faggruppe i kroppsøving under utviklingen av 5-årig grunnskolelærerutdanning

\section{Referanser}

Annerstedt, C. (2001). Varför undervisa i ämnet idrott och hälsa. I C. Annerstedt, B. Peitersen \& H. Rønholt (Red.), Idrottsundervisning (s. 123-144). Gøteborg: Multicare Förlag AB og Forlaget Hovedland.

Arnesen, T. E., Nilsen, A.-K. \& Leirhaug, P. E. (2013). «Den læreplanen som ikkje kan tilpassast mi undervisning, finst ikkje.» Vurdering og undervisning i kroppsøving etter Kunnskapsløftet. FoU i Praksis, 7(3), 9-32.

Arnold, P. J. (1988). Education, Movement and the Curriculum. London: The Falmer Press.

Cardinal, B. J., Yan, Z. \& Cardinal, M. K. (2013). Negative experiences in physical education and sport: How much do they affect physical activity participation later in life? Fournal of Physical Education, Recreation and Dance, 84(3), 49-53. doi.org/10.1080/07303084.2013.767736.

Dowling, F. (2010). Fysisk aktivitet og god helse i kroppsøvingsfaget: Problematisk, ikke automatisk. I K. Steinsholt \& K. Pedersen Gurholt (Red.), Aktive liv (s. 205-218). Trondheim: Tapir Akademiske forlag.

Engebretsen, B. (2016). Dannelse som didaktisk begrep i kroppsøving. I E. E.Vinje (Red.), Kroppsøvingsdidaktiske utfordringer (s. 93-114). Oslo: Cappelen Damm Akademisk.

Enright, E. \& O’Sullivan, M. (2010). 'Can I do it in my pyjamas?' Negotiating a physical education curriculum with teenage girls. European Physical Education Review, 16(3), 203-222. doi: 10.1177/1356336X10382967.

Esser-Noethlichs, M. (2016). Hvordan kan dannelsesprosesser fremmes i kroppsøving? I E. E. Vinje (Red.). Kroppsøvingsdidaktiske utfordringer (s. 115-142). Oslo: Cappelen Damm Akademisk.

Fisette, J. L. (2011). Exploring how girls navigate their embodied identities in physical education. Physical Education and Sport Pedagogy, 16(2), 179-196. doi:10.1080/17408989.2010.535199.

Kvikstad, I. \& Sandell, M. B. (2016). Kroppsøving og fair play-begrepet. I E. E. Vinje (Red.). Kroppsøvingsdidaktiske utfordringer (s. 67-92). Oslo: Cappelen Damm Akademisk. 


\section{Motstridende mål $i$ kroppsøving $i$ Norge - en analyse av lareplanene}

Lyngstad, I. (2013). Profesjonell kunnskap i skolens kroppsøvingsfag. Teoretisk og empirisk belysning i et fenomenologisk og praksisrelatert perspektiv. (Doktorgradsavhandling). Norges teknisk-naturvitenskapelige universitet, Trondheim.

Lyngstad, I. (2014). A shared secret. Sport, Education E Society, 19(2), 153-167. doi.org/10.1080/13573322. 2011.652612.

Lyngstad, I., Hagen, P-M., \& Aune, O. (2016). Understanding pupils' hiding techniques in physical education. Sport, Education E Society, 21(8). doi:10.1080/13573322.2014.993960

Møller, L. (2016). Ballspillundervisning i et dannelsesteoretisk perspektiv. I E. E. Vinje (Red.), Kroppsøvingsdidaktiske utfordringer (s. 143-169). Oslo: Cappelen Damm Akademisk.

Ommundsen, Y. (2016): Danning i kroppsøving: motorisk læring som kjerne i faget. I I. Kvikstad (Red.), Motorikk $i$ et didaktisk perspektiv (s. 139-166). Oslo: Gyldendal akademisk.

Standal, Ø. F. (2015). Phenomenology and Pedagogy in Physical Education. Oxon and New York: Routledge.

Säfvenbom, R. (2010). Om å lede de unge ut i fristelse - og det gode liv. I K. Steinsholt \& K. Pedersen Gurholt (Red.), Aktive liv (s. 155-174). Trondheim: Tapir Akademiske forlag.

Säfvenbom, R., Haugen, T. \& Bulie, M. (2015). Attitudes toward and motivation for PE. Who collects the benefits of the subject? Physical Education and Sport Pedagogy, 20(6), 629-646. Advance online publication. doi: 10.1080/17408989.2014.892063.

Tischler, A. \& McCaughtry, N. (2011). PE is Not for Me: When Boys' Masculinities Are Threatened. Research Quarterly for Exercise and Sport, 82(1), 37-48. doi:10.1080/02701367.2011.10599720.

Utdanningsdirektoratet. (2006). Lareplan i kroppsøving. Hentet 10.09.2017 fra http://www.udir.no/k106/KRO1-01/

Utdanningsdirektoratet. (2012). Lcereplan i kroppsøving. Hentet 10.09.2017 fra http://www.udir.no/k106/KRO1-03/

Utdanningsdirektoratet. (2015). Lareplan i kroppsøving. Hentet 10.09.2017 fra http://www.udir.no/k106/KRO1-04

Utdanningsdirektoratet. (2016). Pressemelding nr. 73-16. Hentet 15.01.2017 fra: https://www.regjeringen.no/ no/aktuelt/bedre-svommeopplaring-i-skolen/id2509337/

Utdanningsdirektoratet (2018). Fornyer faget $i$ skolen. Pressemelding nr 132-18. Hentet 22.11.2018 fra https:// www.regjeringen.no/no/aktuelt/fornyer-innholdet-i-skolen/id2606028/

Vinje, E. E. (2016). Kroppsøvingsfaget i dag og i morgen: hva, hvordan og hvorfor? I E. E. Vinje (Red.). Kroppsøvingsdidaktiske utfordringer (s. 11-31). Oslo: Cappelen Damm Akademisk.

Vinje, E. E. \& Brattenborg, S. (2016). Vurdering i kroppsøvingsfaget - gamle og nye utfordringer. I E. E. Vinje (Red.), Kroppsøvingsdidaktiske utfordringer (s. 32-50). Oslo: Cappelen Damm Akademisk.

van Seelen, J. (2012). Læring, praksis og kvalitet i idrætstimerne. (Doktorgradsavhandling) University of Southern Denmark, Odense.

Zoglowek, H. (2006). Kroppsøving = kroppsdannelse, hva ellers? Kroppsøving, 4, 12-16. 